\title{
PENGARUH IKAN PATIN DAN IKAN GABUS TERHADAP KARAKTERISTIK FISIK MP-ASI INSTAN
}

\author{
EFFECT OF CATFISH (Pangasius Sp) AND SNAKEHEAD FISH (Channa Striata) ON \\ CHARACTERISTICS OF INSTANT BABY PORRIDGE
}

\author{
Choiroel Anam, Kawiji, Reyhan Farha, Usada Nur Ariyoga, dan Nur Her Riyadi P \\ Program Studi Ilmu dan Teknologi Pangan, Fakultas Pertanian, Universitas Sebelas Maret, Surakarta \\ Jl. Ir. Sutami 36A Kentingan Jebres Surakarta 57126 \\ Email: choiroelanam@staff.uns.ac.id
}

Diserahkan [4 Desember 2019]; Diterima [13 Juli 2020]; Dipublikasi [14 Juli 2020]

\begin{abstract}
Complementary Food for Mother's Milk (MPASI) is food or drink that contains nutrients that are given to babies to meet nutritional needs. MP-ASI is a food transition from liquid form into semi-solid food. One food that can be used as MP-ASI material is cork fish and catfish. This study aims to determine the MP-ASI porridge's physical characteristics on the addition of cork fish and catfish. The experimental design in this study used a complete randomized design (CRD) with one factor, namely the combination of added catfish and cork fish $(5 \%, 1015$, and 15\%). The data is processed statistically using one way ANOVA with a significance level of $5 \%$. The results of the research data show that the physical character of MP-ASI instant porridge contains the density of kamba (0.444-0.577\%) the value of good kamba density is to have a large value because to meet the space / volume a large weight is needed, whereas cage denistas which have small values cause material that has a small weight but has already filled the space / volume, the results of research data Water Absorption (0,250$0,484 \%)$, Water absorption is one of the physical properties used to find out how much water is absorbed in each gram of material. Instant baby food MPASI porridge shows a fast rehydration time, so that it will be shorter so that the product absorbs water. The results of the research data show the solubility (34.38-47.81\%) The solubility of the material is expressed as the ability of the material to dissolve into water. The highest solubility or close to $100 \%$ is undesirable because the product will be more soluble in water so that the product will be liquid. This is not in accordance with the purpose of introducing MP-ASI porridge to infants, namely introducing solid food.
\end{abstract}

Keywords: Baby Porridge, Catfish, Snakehead Fish

\begin{abstract}
ABSTRAK
Makanan Pendamping Air Susu Ibu (MP ASI) adalah makanan atau minuman yang mengandung zat gizi yang diberikan kepada bayi untuk memenuhi kebutuhan gizi. MP-ASI merupakan makanan transisi dari yang berbentuk cair menjadi makanan semi padat. Salah satu bahan pangan yang dapat dimanfaatkan sebagai bahan MP-ASI adalah ikan gabus dan ikan patin. Pada penelitian ini bertujuan untuk mengetahui karakteristik bubur MP-ASI secara fisik pada penambahan ikan gabus maupun ikan patin. Rancangan percobaan dalam penelitian ini menggunakan rancangan acak kengkap (RAL) dengan satu faktor yaitu kombinasi penambahan ikan patin maupun ikan gabus $(5 \%, 1015$, dan 15\%). Data diolah secara statistik menggunakan one way anova dengan taraf signifikasi 5\%. Hasil data penelitian menunjukan bahwa karakter fisik bubur MP-ASI instan mengandung densitas kamba $(0,444-0,577 \%)$ nilai densitas kamba yang baik adalah memiliki nilai yang besar karena untuk memenuhi ruang/volume dibutuhkan bobot yang besar, sedangkan denistas kamba yang meiliki nilai kecil menyebabkan bahan yang memiliki bobot yang kecil akan tetapi sudah memenuhi ruang/volume, hasil data penelitian Daya serap Air (0,250-0,484\%), Daya serap air merupakan salah satu sifat fisik yang digunakan untuk mengetahui berapa banyak air yang diserap dalam tiap gram bahan. Bubur MPASI instan baik menunjukkan waktu rehidrasi yang cepat sehingga akan lebih singkat sehingga produk dalam menyerap air. Hasil data penelitian menunjukkan kelarutan $(34,38-47,81 \%)$ Kelarutan bahan dinyatakan sebagai kemampuan bahan untuk larut kedalam air. Sifat kelarutan tertinggi atau mendekati $100 \%$ tidak dikehendaki karena produk akan semakin larut dalam air sehingga produk akan berbentuk cair. Hal ini kurang sesuai dengan tujuan pengenalan bubur MP-ASI ke bayi yaitu memperkenalkan makanan padat.
\end{abstract}

Kata Kunci : MP-ASI Instan; Ikan Patin; Ikan Gabus 


\section{PENDAHULUAN}

Usia bayi selalu bertambah dan meningkatkan kebutuhan akan makanan yang berbeda jenisnya. Bagi bayi berusia 0-6 bulan, pemberian ASI dapat mencukupi untuk pertumbuhan dam perkembangannya, mengingat ASI merupakan sumber zat gizi yang sangat baik untuk bayi. Tetapi saat bayi berusia 6 bulan, ASI tidak mencukupi kebutuhan gizi bayi, oleh karena itu bayi perlu mendapat makanan pendamping agar gizinya dapat terpenuhi. Makanan Pendamping Air Susu Ibu (MP-ASI) adalah makanan atau minuman untuk memenuhi kebutuhan gizi pada anak/balita (Trahms CM dan McKean KN, 2008). Protein dan vitamin A adalah zat gizi yang penting untuk dipenuhi pada masa bayi. Protein untuk bayi berperan dalam pertumbuhan dan pemeliharaan sel, sedangkan vitamin A berperan dalam fungsi sistem imun, melindungi integritas sel-sel epitel lapisan kulit, permukaan mata, bagian dalam mulut, serta saluran pencernaan dan pernafasan.(Parízková,2010).

Pemerintah dalam rangka meningkatkan angka gizi pada anak/balita juga mengatur Pembuatan MP-ASI bubur bayi instan utamanya harus memenuhi kebutuhan gizi bayi yaitu, kandungan energi minimal 400 Kkal, kandungan protein sebesar 15-22 g, dan vitamin A sebesar 250-350 $\mu \mathrm{g}$ dalam $100 \mathrm{~g}$ bahan. Pada umumnya bahan penyusun MP-ASI bubur bayi instan berasal dari campuran tepung beras, susu skim, gula halus, dan minyak nabati. Untuk meningkatkan dan memperkaya kandungan gizi, bahan-bahan tersebut dapat disubstitusi dengan bahan pangan lokal sumber protein dan vitamin A. (Andarwulan, 2004).

Salah satu bahan pangan lokal sumber protein yang dapat dimanfaatkan sebagai bahan MP-ASI adalah ikan gabus dan ikan patin. Menurut Astawan (2009), kandungan protein ikan gabus lebih tinggi daripada bahan pangan lain yang dikenal sebagai sumber protein seperti telur, daging ayam maupun daging sapi. Kadar protein per $100 \mathrm{~g}$ ikan gabus adalah 25,20 g dan lebih tinggi dibandingkan telur sebesar 12,8 g, daging ayam sebesar 18,2 g serta daging sapi sebesar
18,8 g. Selain itu nilai cerna ikan sangat baik, yaitu mencapai lebih dari $90 \%$. Sedangkan Ikan patin merupakan ikan air tawar yang mudah dijumpai dan mempunyai kandungan protein sebesar 68,6 \%. (Gam dkk., 2006).

Pemenuhan kebutuhan vitamin A pada bayi salah satunya dapat digunakan bahan dari labu kuning, bayam dan kacang merah. Karena labu kuning atau waluh (Cucurbita moschata Durch) memiliki kandungan gizi yang cukup lengkap. Menurut Gardjito (2006), kadar beta karoten daging buah labu kuning segar adalah 19,9 mg/100 g. Sedangkan bayam merupakan sejenis tumbuhan yang mengandung $\mathrm{Fe}$ dan bayam juga mengandung Vitamin A,B, dan $\mathrm{C}$. selain itu bayam mengandung mineral yang penting seperti kalsium, fosfor, dan besi (Sunarjono, 2003). Kacang merah adalah sumber karbohidrat kompleks, serat, vitamin B, folasin, tiamin, kalsium, fosfor dan zat besi (Salunkhe,2007). Tujuan dari penelitian ini adalah mengetahui pengaruh penambahan ikan patin dan ikan gabus terhadap karakteristik fisik bubur MP ASI instan (densitas kamba, daya serap air, dan kelarutan).

\section{METODE PENELITIAN}

\section{Bahan dan Alat}

Bahan yang digunakan dalam penelitian ini adalah labu kuning berasal dari boyolali, kacang merah, bayam dan ikan gabus berasal dari pasar kota Klaten, ikan patin dari pasar ikan Brajan Surakarta, susu formula merk SGM umur 0-6 bulan, minyak kedelai dari CV cipta kimia surakarta, dan air. Bahanbahan kimia yang digunakan untuk analisis kimia adalah $\mathrm{H} 2 \mathrm{SO} 4, \mathrm{HgO}, \mathrm{K} 2 \mathrm{SO} 4$, Nas2O3), H3BO3), HCL 0,02 N, petroleum eter, $\mathrm{Na}$ fosfat, $\mathrm{HCl} 0,4 \mathrm{~N}$, etanol $95 \%$, enzim pepsin, enzim termamyl, aseton, celite, aquades, HNO3 encer (0,2 M), HNO3 pekat, serbuk Fe, dan alkohol $96 \%$.

Peralatan yang digunakan pada penelitian ini adalah kompor, pengering drum dryer, botol timbang, oven, desikator, kompor listrik, tanur pengabuan, penjepit, timbangan analitik, labu kjeadhl $500 \mathrm{ml}$. pipet volume $50 \mathrm{ml}$, gelas ukur $100 \mathrm{ml}$. erlenmayer $100 \mathrm{ml}$, alat destilasi, pipet tetes, 
buret, sokhlet desikator, penangas air, oven, tabung reaksi, vortex, sentrifugasi, spektrofotometer, cawan porselin, labu takar, buret mikro.

\section{Tahapan Penelitian}

\section{Pembuatan Puree}

Semua bahan utama (labu kuning, bayam, kacang merah, ikan patin, dan ikan Gabus. labu kuning) dibuat puree. Labu kuning dikupas sampai bersih kemudian dicuci dibawah air mengalir setelah itu dilakukan pengukusan kemudian dilakukan penghalusan dengan menggunakan blender. Bayam hijau dipotong dipisahkan daun dan batang kemudian kemudian dicuci dibawah air mengalir sampai bersih setelah itu diblanching, Kacang merah direndam selama 6 jam kemudian dicuci dibawah air mengalir setelah itu dilakukan pengukusan kemudian dilakukan penghalusan dengan menggunakan blender. Ikan gabus dan ikan patin difillet dipisahkan kulit, tulang, dan kepala ikan kemudian dicuci dibawah air mengalir sampai bersih setelah itu dilakukan pengkukusan kemudian penghalusan dengan menggunakan blender.

\section{Pembuatan Bubur MPASI Instan}

Bahan yang digunakan dalam pembuatan bubur bayi terdiri dari puree labu kuning, puree kacang merah, puree bayam hijau, puree ikan patin, puree ikan gabus, susu formula, minyak kedelai dan air, kemudian semua bahan dicampur secara merata kemudian diproses kedalam alat pengering Drum dryer. Prinsip kerja drum dryer adalah bahan dalam bentuk cairan bubur atau adonan yang akan dikeringkan diaplikasikan/diumpankan pada permukaan luar drum yang berputar, sehingga membentuk lapisan tipis $(0,5 \mathrm{~mm}-2 \mathrm{~mm})$ yang seragam menempel dan menyelimuti permukaan drum. Lapisan tipis bahan yang menempel pada permukaan drum panas akan mengalami peningkatan suhu dan penguapan air secara cepat. Jadi, proses pengeringan drum merupakan proses yang unik dimana terjadi proses pemasakan (cooking) dan pengeringan pada waktu yang bersamaan. kemudian bubur MP-ASI instan di analisis secara fisik.

\section{Densitas kamba (Pengujian Sederhana Fardiaz, 1992)}

Densitas kamba diukur dengan cara menentukan berat dan volume wadah, mengisi wadah hingga penuh, menimbang wadah dan sampel, dan menentukan densitas kambanya kadar densitas kamba dihitung sebagai berikut :

$$
\text { Densitas }(\mathrm{g} / \mathrm{ml}): \frac{\text { Berat sampel }(\mathrm{g})}{\text { Volume sampel }(\mathrm{ml})}
$$

\section{Daya serap air (Pengujian Sederhana Fardiaz, 1992)}

Daya serap air dianalisa dengan cara menyiapkan erlenmeyer, corong, dan kertas saring, Diawali dengan menimbang kertas saring, kemudian melipat kertas saring dan diletakkan pada Erlenmeyer, menyiapkan air panas $13 \mathrm{ml}$, menimbang sampel 1-3 gram dan sampel dituangkan pada kertas saring, dilanjutkan dengan menuangkan air panas, kemudian menunggu hingga 10 menit. Tahap berikutnya menimbang kertas saring dan residu dilanjutkan menimbang air pada Erlenmeyer. Kadar daya serap air dihitung sebagai berikut :

Daya serap air $(\%)=\frac{A-B}{C}$

Keterangan :

A : Berat air Mula Mula
B : Berat air yang keluar
C : Berat Sampel

\section{Kelarutan (Pengujian Sederhana Fardiaz, 1992)}

Kelarutan MPASI instan dapat dianalisa berdasarkan pada presentase berat residu yang tidak dapat melalui kertas saring whatman terhadap berat sebanyak sampel $0,5 \mathrm{~g}$ sampel ditimbang dan dilarutkan dalam $50 \mathrm{ml}$ air campuran diaduk untuk memperkecil ukuran sampel supaya mudah larut kemudian disaring dengan kertas saring whatman yang telah diketahui beratnya. Sampel yang tidak tersaring, kemudian dimasukkan oven selama 1 jam pada suhu $105^{0} \mathrm{C}$ lalu didinginkan pada desikator 15 menit kemudian ditimbang. Bobot sampel yang tidak tersaring diperoleh dari selisih bobot kertas saring akhir dengan bobot kertas 
saring awal. Kelarutan dapat dihitung dengan cara sebagai berikut :

Kelarutan
$\left[\left[\frac{\text { berat awal sampel-berat akhir sampel }}{\text { berat awal sampel }}\right] \times 100 \%\right]$

\section{HASIL DAN PEMBAHASAN}

\section{Sifat Fisik MP ASI Bubur Bayi Instan}

\section{Densitas kamba}

Bahan dinyatakan kamba bila mempunyai nilai densitas kamba yang kecil, berarti berat yang ringan membutuhkan volume (ruang) yang besar. Parameter densitas kamba ini dapat digunakan untuk melihat bagaimana kesempurnaan proses pengeringan atau keseragaman bentuk dan ukuran pada bahan (Singh dkk., 2005). Hasil uji nilai densitas kamba MP-ASI ikan patin dan ikan gabus berkisar antara $0,44 \mathrm{~g} / \mathrm{mL}$ 0,57 g/mL seperti pada Tabel 1 .

Nilai densitas untuk makanan berbentuk bubuk umumnya berkisar antara 0,3-0,8 $\mathrm{g} / \mathrm{mL}$ (Tampubolon dkk., 2014). Semua formulasi dalam penelitian ini telah memenuhi persyaratan densitas kamba untuk memenuhi makanan yang berbentuk bubuk. Penelitian ini menunjukkan bahwa semakin banyak penambahan ikan patin maupun gabus dapat meningkatkan nilai densitas kamba. bubur bayi yang memiliki densitas kamba besar memiliki zat gizi lebih banyak daripada bubur bayi yang memiliki densitas kamba yang kecil, dikarenakan produk dengan kepadatan nilai gizi tinggi menempati ruang yang sedikit dalam usus bayi, sehingga semakin banyak zat gizi yang dapat diterima oleh bayi.

Bubur bayi yang memiliki densitas kamba rendah dapat menyebabkan bayi cepat kenyang sehingga menyebabkan asupan gizi yang masuk ke dalam tubuh bayi belum terpenuhi (Elvizahro,2011). Dari penelitian di atas densitas kamba pada penambahan ikan gabus lebih besar dibandingkan dengan penambahan ikan patin sehingga gizi yang dicerna lebih baik bubur bayi instan dengan penambahan ikan gabus daripada dengan penambahan ikan patin

\section{Daya serap air}

Daya serap air merupakan salah satu sifat fisik yang berguna untuk mengetahui banyak air yang terserap setiap gram bahan. Pada produk instan daya serap air yang baik menunjukkan waktu rehidrasi yang digunakan akan lebih cepat sehingga produk lebih mudah menyerap air (farida dkk., 2016)..

Tabel 1 Hasil Uji Kadar Densitas Kamba MPASI Instan

\begin{tabular}{llllllll}
\hline & Kontrol & Patin 5\% & $\begin{array}{l}\text { Patin } \\
10 \%\end{array}$ & $\begin{array}{l}\text { Patin } \\
15 \%\end{array}$ & $\begin{array}{l}\text { Gabus } \\
5 \%\end{array}$ & $\begin{array}{l}\text { Gabus } \\
10 \%\end{array}$ & $\begin{array}{l}\text { Gabus } \\
15 \%\end{array}$ \\
\cline { 2 - 8 } Densitas & $0.444^{\mathrm{a}} \pm$ & $0.453^{\mathrm{a}} \pm 0$ & $0.471^{\mathrm{ab}} \pm$ & $0.484^{\mathrm{b}} \pm$ & $0.483^{\mathrm{b}} \pm$ & $0.514^{\mathrm{c}} \pm$ & $0.577^{\mathrm{d}} \pm$ \\
kamba & 0.014 & .019 & 0.025 & 0.012 & 0.013 & 0.027 & 0.011 \\
\hline
\end{tabular}

Notasi yang berbeda menunjukkan beda nyata pada $\alpha=0,05$

Kontrol $=$ tanpa penambahan daging ikan

Tabel 2 Daya serap air MP-ASI Instan

\begin{tabular}{llllllll}
\hline & Kontrol & Patin & Patin & Patin & Gabus & Gabus & Gabus \\
& & $5 \%$ & $10 \%$ & $15 \%$ & $5 \%$ & $10 \%$ & $15 \%$ \\
\cline { 2 - 8 } Daya Serap Air & $0.250^{\mathrm{a}} \pm$ & $0.412^{\mathrm{b}} \pm$ & $0.355^{\mathrm{ab}}$ & $0.255^{\mathrm{a}} \pm$ & $0.399^{\mathrm{b}} \pm$ & $0.309^{\mathrm{ab}}$ & $0.267^{\mathrm{a}} \pm$ \\
& 0.061 & 0.135 & \pm 0.057 & 0.042 & 0.096 & \pm 0.056 & 0.067 \\
\hline
\end{tabular}

Notasi yang berbeda menunjukkan beda nyata pada $\alpha=0,05$

Kontrol $=$ tanpa penambahan daging ikan 
Tabel 2 menunjukkan bahwa nilai daya serap air diketahui berkisar 0,25g/g-0,48 g/g. Menurut Kusumaningrum dan Winiati, (2007), daya serap air MP-ASI bubur Instan umumnya berkisar antara 3,60-6,20. Hasil penelitian ini menunjukkan bahwa bubur bayi instan berbeda dengan penelitian sebelumnya. Hal ini karena daya serap air dipengaruhi oleh lemak yang terkandung dalam bubur MP-ASI Instan. Semakin tinggi lemak yang terkandung dalam bahan akan menurunkan kemampuan bahan dalam menyerap air. Diketahui bahwa lemak dalam ikan patin lebih tinggi daripada ikan gabus yaitu $20,10 \%$ per 100 g (Elvizahro,2011) sedangkan kadar lemak pada ikan gabus yaitu $0,55 \%$ per $100 \mathrm{~g}$ (Syafitri dan Etika,2015), sehingga kadar daya serap air pada penambahan ikan patin lebih tinggi daripada ikan gabus.

\section{Kelarutan}

Kelarutan air merupakan salah satu sifat fisik produk bubuk yang berhubungan dengan proses rehidrasi penyajian. Kelarutan bahan dinyatakan sebagai kemampuan bahan untuk larut kedalam air (Hidayat,2009). Sifat kelarutan tertinggi atau mendekati 100\% tidak dikehendaki karena produk akan semakin larut dalam air sehingga produk akan berbentuk cair. Hal ini kurang sesuai dengan tujuan pengenalan bubur MP-ASI ke bayi yaitu memperkenalkan makanan padat ke bayi (Husna dkk.,2012). Kelarutan atau disperbilitas memiliki peranan penting terhadap mouthfeel (kasar, halus, lembut, berpasir) makanan yang dikonsumsi.

Tabel 3 menyampaikan kelarutan pada bubur MP-ASI Instan adalah 34-47\%. Kelarutan bubur bayi tidak mendekati $100 \%$ karena dengan kelarutan ini produk akan larut sempurna didalam air maka tidak baik untuk bayi karena tujuan dari makanan pendamping MP-ASI adalah untuk memperkenalkan bayi dengan makanan padat (Husna dkk.,2012). Pada penelitian ini nilai tertinggi kelarutan adalah pada sampel kontrol sedangkan rata-rata nilai kadar kelarutan pada penambahan ikan patin memiliki kadar kelarutan lebih tinggi daripada pada penambahan ikan gabus. Kelaruta ini dapat mempengaruhi daya terima bayi, karena bayi akan menerima MPASI dengan karakter tekstur lembut (sesuai dengan kemampuan pencernaannya), lebih menyukai rasa manis, rasa gurih yang diberi garam, dan menolak rasa pahit, serta menyukai flavor tergantung waktu pertama kali diperkenalkan dengan MP-ASI. (Aprilia V dan Febrina S H., 2016).

Tabel 3 Kelarutan MPASI Instan

\begin{tabular}{llllllll}
\hline & Kontrol & Patin 5\% & Patin & Patin & Gabus & Gabus & Gabus \\
Kelarutan & & & $10 \%$ & $15 \%$ & $5 \%$ & $10 \%$ & $15 \%$ \\
\cline { 2 - 7 } & $47.81^{\mathrm{e}} \pm$ & $41.85^{\mathrm{d}} \pm 1$ & $36.77^{\mathrm{c}} \pm 1$ & $35.11^{\mathrm{ab}} \pm$ & $41.89^{\mathrm{d}} \pm$ & $36.52^{\mathrm{bc}} \pm$ & $34.38^{\mathrm{a}} \pm$ \\
& 0.56 & .05 & .215 & 1.218 & 1.10 & 0.73 & 1.04 \\
\hline
\end{tabular}

Notasi yang berbeda menunjukkan beda nyata pada $\alpha=0,05$

Kontrol = tanpa penambahan daging ikan

\section{KESIMPULAN}

Berdasarkan hasil penelitian yang telah dilakukan diperoleh kesimpulan bahwa kelarutan berkisar berkisar 0,44 g/mL-0,57 $\mathrm{g} / \mathrm{mL}$. Semua formulasi telah memenuhi persyaratan SNI. Daya serap air berkisar antara $0,25 \mathrm{~g} / \mathrm{g}-0,48 \mathrm{~g} / \mathrm{g}$, daya serap air pada penambahan ikan patin lebih tinggi daripada ikan gabus. Kelarutan MP-ASI instan pada penelitian ini mencapai $34-47 \%$. dengan nilai tertinggi kelarutan pada sampel kontrol. Namun demikian rata-rata kelarutan pada penambahan ikan patin mempunyai kelarutan lebih tinggi dibandingkan kelarutan pada penambahan ikan gabus.

\section{UCAPAN TERIMA KASIH}

Ucapan terima kasih terutama ditujukan kepada Universitas Sebelas Maret Surakarta yang telah memberikan fasilitas atas keberlangsungan penelitian ini. Ucapan terima kasih juga ditujukan kepada pihakpihak yang telah membantu dalam 
terlaksananya penelitian yang tak bisa disebutkan satu persatu.

\section{DAFTAR PUSTAKA}

Andarwulan N, Fatmawati S.2004. Formulasi Bubur Bayi Berprotein Tinggi dan Kaya Antioksidan dari Tepung Kecambah Kacang Tunggak (Vigna unguilucata) untuk Makanan Pendamping ASI. Prosiding Seminar Nasional dan Kongres Perhimpunan Ahli Teknologi Pangan Indonesia.

Aprilia V , Febrina Suci Hati, 2016, Formulasi bubur bayi MPASI yang diperkaya hidrolisat

protein ikan lele dumbo (Clarias gariepinus), Jurnal Gizi Dan Dietetik Indonesia, Vol. 4, No. 2, Mei 2016: 8896

Astawan, M. (2009). Ikan Gabus Dibutuhkan Pascaoperasi. Nutrition Mon. (2nd edn)

Elvizahro, Leyla., Etika Noer., Ninik Rustanti.2014. Karakteristik Makanan Pendamping Balita yang Disubtitusi dengan Tepung Ikan Patin dan Labu Kuning.Vol 2 No 2 Juni 2014 :82-89

Fardiaz. S. 1992. Mikrobiologi Pangan I. Gramedia Pustaka Utama. Jakarta. Hal 22-23

Farida, Salis Nur., Dwi Ishartani., Dian Rachmawanti Affandi. 2016. Kajian Fisik, Kimia dan Sensoris Bubur Instan Berbahan Dasar Tepung Tempe Koro Glinding (Phaseolus lunatus), Tepung Beras Merah (Oryza nivara) dan Tepung Labu Kuning (Cucurbita moschata). Jurnal Teknosains Pangan Vol 5 No 4 Hal 212-213

Gam, Lay-Harn., Chiuan-Yee Leow., and Saringat Baie. 2006. Protemic Analysis of snakehead Fish (Channa striata) Tissue. Malaysian Journal of Biochemistry and Molecular Biology (2006) 14, 25-32.

Gardjito, M . (2006). Labu Kuning Sumber Karbohidrat Kaya Vitamin A 2nd edn. Tridatu Visi Komunikasi. Yogyakarta

Hidayat, Beni., Kalsum Nurbani dan Surfiana. 2009. Karakterisasi Tepung Ubi kayu modifikasi yang diproses menggunakan Metode pragelatinisasi parsial ( Characteristzation pf modified Cassava flour processed Through Partial Pregelatinisation Method). Jurnal Teknologi Industri dan hasil Pertanian Volume 14, No 2 Hal 100-102

Husna, Emma A., Dian Rachmawati Affandi.. Kawiji., R. Baskara Katri Anindito. 2012. Karakterisasi Bubur Bayi Instan Berbahan Dasar Tepung Millet (Panicum sp) dan tepung Kacang Hijau (Phaseolus Radiatus) dengan flavor alami pisang ambon ( Musa Paradisiaca var. Sapientum L).Jurnal Teknosains Pangan Vol 1 No 1 Hal 5557

Kusumaningrum, Aryani., dan Winiati $\mathrm{P}$ Rahayu. 2007. Penambahan kacangkacangan Dalam Formulasi Makanan Pendamping Air Susu Ibu (MP-ASI) Berbahan dasar Pati Aren( Arenga Pinnata (Wurmb) Merr). Jurnal Teknologi Industri Pangan, Vol XVII No. 2 Hal 20-22 Th 2007

Parízková J.(2010) Nutrition, Physical Activity, and Health in Early Life 2nd edn. CRC Press. USA

Salunkhe DK, Kadam SS, Chavan JK. (2007). Postharvest Biotechnology of Food Legumes. Boca Raton Florida. CRC Press. USA

Singh, Kaur L., Sadhi NA, Sekhon KS. 2005. Physicoschemical, Cooking, and Textural properties of miled Rice from different Indian Rice Cultivars Food Chem. 89 ;253-259

Sunarjono. (2003). Fisiologi Tanaman Budidaya. UI Press. Jakarta.

Syafitri, Dian dan Etika Noer .2015. Pengaruh Subtitusi Tepung Ikan Gabus dan Labu Kuning Terhadap Kandungan Zat gizi dan Tingkat Kesukaan Makanan Pendamping Air Susu Ibu (MP-ASI) Bubur Instan. Skripsi Program Studi Ilmu Gizi Fakultas Kedokteran Universitas Diponegoro. Semarang

Tampubolon, Nurita L., Terip K. dan Ridwansyah.2014. Formulasi Bubur Bayi Instan dengan Subtitusi Tepung Tempe dan Tepung Labu Kuning Sebagai Alternatif Makanan 
Pendamping ASI. Jurnal Rekayasa

Pangan dan Pertanian Vol 2 (3) : 78-83

Trahms CM, McKean KN.(2008) Nutrition

During Infancy. In: Mahan LK, EscottStump S. Krause's Food and Nutrition

Theraphy 12th edn. Elsevier. Canada. 